\title{
Gazing Geometries: Modes of Design Thinking in Pre-Modern Central Asia and Persian Architecture
}

\author{
Hooman Koliji ${ }^{1}$
}

Published online: 30 March 2016

(C) Kim Williams Books, Turin 2016

\begin{abstract}
The architecture of the pre-modern Islamic world broadly identifies itself with geometric design. In erecting buildings, architects-engineers of the Islamic world utilized distinct modes of geometric projections vital to the spatial conception of the building. These representations identify three modes of design drawings: plans, revetments/vertical surfaces, and reflected ceiling plans. This paper will discuss these modes of drawings and their unique role in relation to the architectural "design thinking" traditions. Much has been examined regarding twodimensional Islamic geometric patterns (girih), but little exists in terms of a comprehensive framework investigating various modes of geometric drawings in relation to formal, spatial, and tectonic conceptions of the architectural space. This paper fills a critical gap in the literature about Islamic architecture and examines this topic through primary resources and original pamphlets.
\end{abstract}

Keywords Pre-modern Islamic architecture - Architectural drawings ·

Representation · Girih patterns · Geometry

\section{Geometric Conception and Islamic Architecture}

The architecture of the pre-modern Islamic world broadly identifies itself with geometric design and conception. Sophisticated earth (brick) structures were sheathed in geometrically complex revetments, and culminated in complex vault structures made possible thanks to knowledge of applied geometry and mathematics. Geometry was regarded as a transformative design agency to bring to order the untamed raw materials in a spatial fashion. Geometry was routinely celebrated

Hooman Koliji

koliji@umd.edu

1 School of Architecture Planning and Preservation, University of Maryland,

College Park, MD, USA 
through highlighted details and glazed ornaments. However, pre-modern architectural design in the Islamic world also had a subtle relationship with design drawings.

Scattered surviving design drawings range over a long chronological period. The list of authors and intended users is also inclusive, and includes mathematicians and astronomers as well as builders and craftsmen. This inclusiveness calls for an understanding of the identity and role of the architect in pre-modern Islamic architecture different from that of the West, where the architect was principal designer. Historical accounts render a multifaceted identity and role for the architect in terms of design and building processes. Repeated use of various qualifiers such as mi'mar (architect), muhandis (geometer), ustad or ustadh, (master craftsman), or banna (builder) depict individuals responsible in conceiving buildings.

In his Islamic Architects and Their Works (1956), Leo Ary Mayer collected an extensive list of some 350 Islamic architects, engineers, and master masons from the rise of Islam to $1830 \mathrm{AD}$, and noted that very little is known about the status, training, and on-site responsibilities of architects. Mayer did not distinguish between masons and craftsmen working in various disciplines and mentions some architects as "stone-cutters or sculptors in plaster ..." (Mayer 1956: 12). Mayer's work reveals complexities in the role and identity of the Islamic architect, and thus in the design process. His work portrays an image of architectural practice that is more nuanced compared to that of the West and is more collective in terms of participation of various individuals (master craftsmen, engineers, builders, stonecutters, and even patrons), questioning the role of the architect as sole principal designer.

Mayer, however, did not provide an in-depth discussion of the hierarchical role of individuals in practice. Donald Wilber noticed this gap in Mayer's work and argued for an emphasis on "the role of the craft system in construction: the name of ustadh (master craftsman) on a building implies that he supervised the work of apprentices who learned through doing and who tended to preserve established methods and patterns" (Wilber 1956: 253). Providing parallels between Mamluk and Timurid architecture, Nasser Rabbat verifies the diversity of knowledge and craftsmanship involving architecture and hierarchy and mastery of the architect, which also consolidates Mayer's and Wilber's views. Rabbat depicts diverse identities for the role of the architect, yet discovers a hierarchical path towards becoming a master architect, as architects had to "transform themselves intellectually and socially to move beyond confines of small-time artisanal limitations. ...to become something else, in addition to being artist and builders" (Rabbat 1998: 36). Most often, in addition to being a polymath, it was the higher knowledge of geometry that granted a distinguished status for the architect. Nevertheless, geometric conceptions were core to engineering (muhandisi), drawing (tarh), architecture (mi'mari), and most fields of the crafts (san'at).

This brief overview demonstrates the nuanced design thinking process involved in pre-modern Islamic architecture. This process appears to have been a collective effort involving various individuals of masons and craftsmen. It is likely that the more significant the status of the edifice or the patron, the higher the status of the master (architect). In that case, the master architect might have called for some level of design drawing (tarh) from his craftsmen. 
Surviving drawings include a range of geometric drawings that can be applied to two-dimensional and three-dimensional surfaces, as well as unelaborated plan drawings. These drawings suggest three categories: grid-based plan drawings, twodimensional geometric drawings for ornamentals on revetments and vertical surfaces, and three-dimensional geometric drawings demonstrating ornaments as well as semi-structural designs of ribs in vaults and domed spaces. The categories in the collection of the drawings, however, did not emerge at once; rather, they developed chronologically over a period of eight centuries. For example, in the tenth and eleventh centuries, one can find evidence of early geometric drawings that pertain to two-dimensional surfaces. A rare surviving thirteenth-century inscribed plaster (Fig. 1) demonstrates geometric drawing for three-dimensional space, and later, in the sixteenth and seventeenth centuries, we find evidence of plan drawings. By the nineteenth century, all of these categories of drawings seem to be at work.

This paper's focus is on geometrical design thinking in Islamic architecture evidenced through surviving historical drawings and texts. Collectively, these drawings present three modes of design thinking, and suggest envisioning architecture through plan drawings, revetment ornamentations, and reflected ceiling plans. The paper aims to discuss these distinct modes of geometric drawings and will examine the unique role that each played in design.

It is useful to compare the three categories of drawings found in Islamic architecture to the Vitruvian categories of Ichnographia, Orthographia, and Scenographia. In the Vitruvian model, the ideae of the building is contained within these three modes of drawing. Vitruvius's two first categories correspond to plan and elevation drawings, and the third one - a rather curious one-suggests either the profile of a building or a mode of section showing depth. In the classification that I argue for, only plan drawings slightly correspond to the Vitruvian categories. Ichnographia as explained by Vitruvius is a relatively accurate representation of the future building in plan mode, which includes the expression of some level of detail.
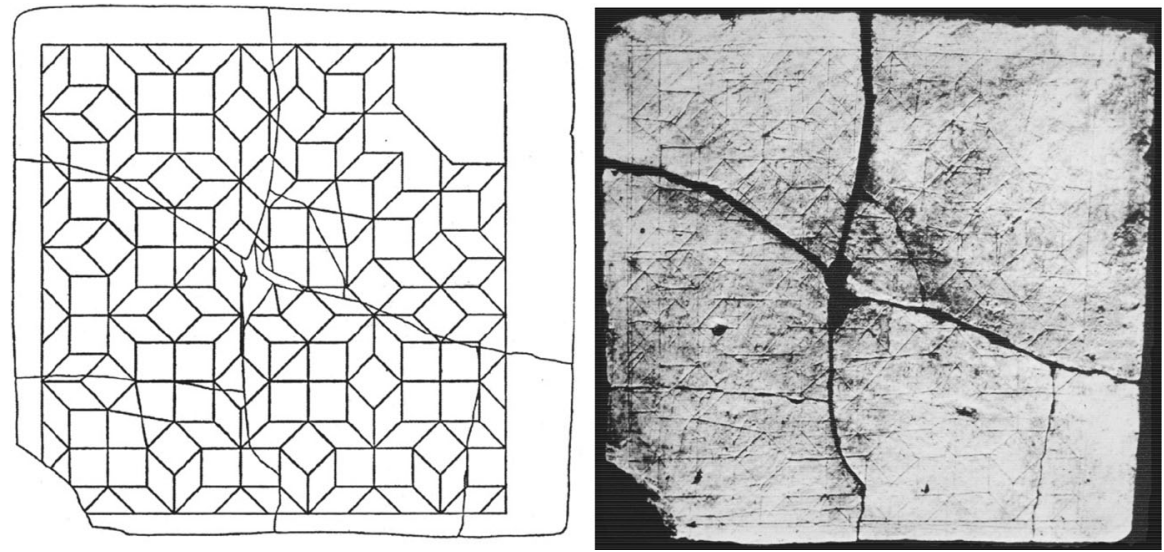

Fig. 1 Plan of muqarnas on a thirteenth-century incised plaster slab showing a quarter or half of a muqarnas vault. C. 1270, Takht-i Sulayman, Iran. Courtesy of Deutches Archaologisches Institute, Abeilung, Tehran, Iran 
Similarly, Orthographia is the frontal view of the building, which includes elemental details such as doors and windows, and their relationship to the entirety of the frontal appearance of the building. Elevation drawings are conspicuously absent in Islamic architectural design drawings. While miniature-style drawings occasionally depict elevation views of buildings, there is no evidence that architects of the time exercised design through elevation drawings. Scenographia was a bit more complex to capture. It had to do with the interior experience of the building-but it was not represented as a section drawing in the same way that the idea of section (derived from dissecting) was introduced much later in the eighteenth century. Scenophraphia, as explained by Sebastiano Serlio (1475-1554), corresponds to profilo, or profile, which also expresses the interior volume of the building, often in a semi-perspectival appearance. In Islamic architecture, section drawings are also absent. Mirza Akbar's late-nineteenth-century drawings show some snipped studies of profile of arches or vaults, but remain very abstract. The absence of elevation and section drawings in early Islamic architecture can be explained: "these drawings were not seen as essential to the process of design and construction in medieval Islam" (Yousefi 2005: 19). Nevertheless, it also shows a fundamental difference in the design process compared to that of the West and contemporary practice.

The Vitruvian view of modes of drawings eventually evolved to a view based on descriptive geometry, and became the dominant practice in the eighteenth century, following the work of French mathematician Gaspard Monge (1746-1818). His work on descriptive geometry shaped the Western view of architectural representation to technical drawings utilizing geometry. French architect and educator JeanNicolas-Louis Durand (1760-1834), Monge's contemporary, is regarded as the first to advocate for the use of descriptive geometry in architecture. In pre-modern Islamic architecture, the use of descriptive geometry was not present until the early twentieth century, and derived from a Western influence.

Additionally, unlike in the West, where architectural drawings were typically maintained in sketchbooks (for example, French tradition of documenting geometric exercises) or in treatises (for example, Serlio), preserving a drawing was not a common practice in the Islamic world. With little evidence of textual writings by architects, engineers, and craftsmen, it is hard to achieve assurance as to how designers of the time made their decisions. This becomes more complicated when visual materials such as drawings are not in abundance. On rare occasions, drawings were preserved and presented to royal building's patrons, and were maintained in the royal court. It is likely that, since most drawings were geometric in nature, they were executed on site and eventually consumed during construction. For example, we could refer to a rare plaster drawing of muqarnas ${ }^{1}$ from the thirteenth century, recovered from Takht-i Sulayman, which demonstrates a geometric exercise for a three-dimensional vault space (Fig. 1).

However, surviving documents do universally address the use of geometry in architectural design of the medieval Islam. They vary from grid-based plans that develop semi-abstract geometric patterns to semi-tectonic spatial design. Most of these historical references comprised treatises of practical geometry by

\footnotetext{
${ }_{1}$ Muqarnas refers to a characteristic form of ornamented architectural vaulting.
} 
mathematicians and geometers for architects and artisans who had to apply those principles in their geometric designs.

\section{Practical Geometry: The Design and Construction of Geometric Drawing}

To better understand why design drawings of Islamic architecture were identified with geometric patterns, one must go back to the rise of the use of geometry in practical fields. The treatises of practical geometry handed down to the makers were widely used from the tenth to the thirteenth centuries to configure geometric pattern drawings for practice purposes. These geometric patterns were based on the fundamental notion of $a q d$, which is an Arabic word denoting 'knot'. Since the eleventh century aqd has been used to refer to interlocking geometric patterns. Persians used term girih (also meaning knot) and referred to various geometric patterns as using different types of girih designs. According to Gülru Necipoğlu (1986), the emergence of girih is attributed to tenth-century Baghdad, where the Islamic scientific evolution of the House of Wisdom (that is, Bayt al-Hikma) began. The use of the circle is fundamental to the conception of girih and its development to larger patterns.

Early documents depicting girih were reported by the Persian polymath and astronomer, Abu al-Wafa Buzjani (940-998). His treatise entitled A Book on Those Geometric Constructions Which Are Necessary for a Craftsman (Buzjani and Jazbi 2005) is the first known source that addressed the design of geometric patterns in a systematic way. In his treatise, which seems to have been developed for craftsmen and artisans, Buzjani explains the use of geometry for conceiving shapes and figures, mainly those derived from circles. ${ }^{2}$ He devoted three entire chapters (3-5) to describing various methods for drawing polygons within a circle and vice versa, as well as arguing for a methodical approach to the use of geometry in carpentry and architecture. Importantly, Buzjani disapproved of experimental methods of dividing a circle's perimeter to equilateral shapes; instead, he argued for the use of accurate and methodical calculations. Buzjani's documented method for drawing polygons and shapes within other shapes is one of the earliest manuals that informed the practice of architects and craftsmen. Buzjani's treatise is mainly a manual to explain geometric problems and ways to realize them in practice. For example, three types of geometric problems included constructions using rusty compass, dissecting squares, and the projection of

\footnotetext{
2 The book includes twelve chapters, as well as an introduction entitled "On Understanding the Straightedge, Compass, and Square", which discusses the importance of using accurate tools for facilitating the truthfulness of geometric practices. His book is the first known manual on drawing and on drawing tools in Islamic culture. His use of language-for example, in the "truthfulness" of a straightedge -implies an expectation beyond a merely physical accuracy of the drawing tool, but rather attaining an ideal straight line. To measure the accuracy of the straightedge, however, he suggests an experimental method: to draw a line with an edge and repeat the line with the same flipped edge. Once the two lines fully overlap, then the straightedge is "truthful".
} 
Fig. 2 Page from F̄̄ tadākhul al-ashkāl al-mutashābiha aw almutawāfiqa explaining execution of the girih in Persia circa the tenth to thirteenth centuries. Bibliotheque

Nationale de France, Ms. Persan 169 , fol. $180 \mathrm{v}$

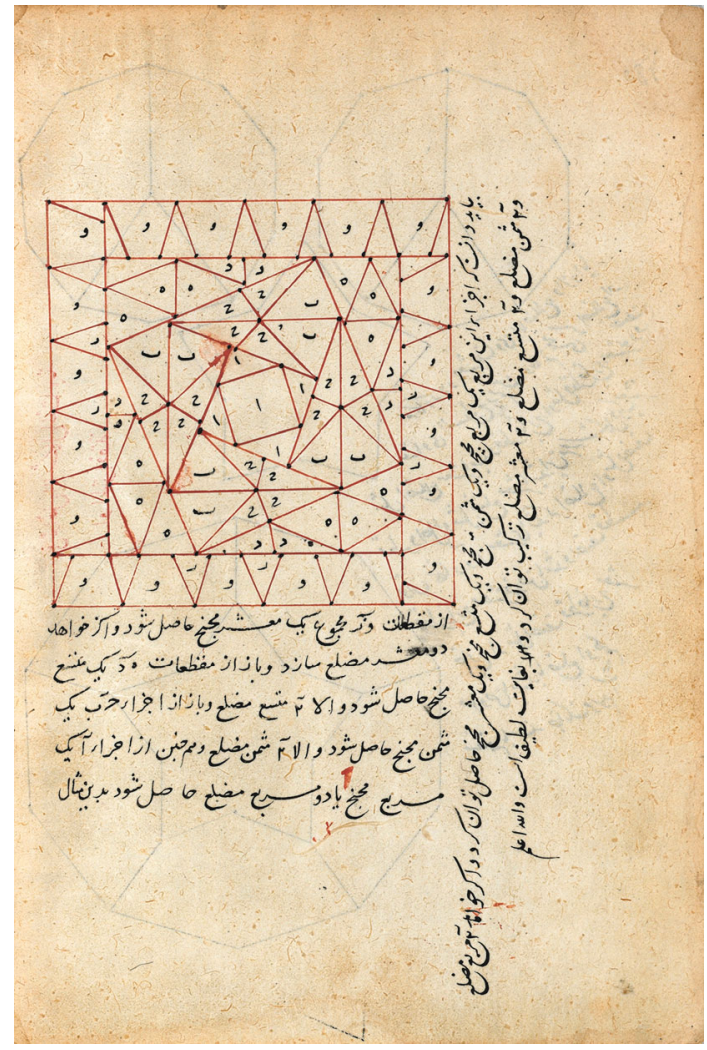

regular and semi-regular polyhedra on spheres. ${ }^{3}$ While Buzani's treatise does not describe the geometric problems in terms of girih, it is safe to say that they can be viewed as the fundamental structure and grammar for creating the interlocking geometric pattern, girih.

An anonymously authored appendix to Buzjani's treatise also provides glimpses of the depth of geometric pattern discoveries in the eleventh to thirteenth centuries. This document, $F \bar{l}$ tadākhul al-ashkāl al-mutashābiha aw al-mutawāfiqa (On Interlocking Similar or Congruent Figures, now conserved as ms. Persan 169 in the Bibliotheque Nationale de France in Paris) introduces about 110 various geometric problems including transformational puzzles, girih patterns, and other geometric constructions (Figs. 2, 3, 4). ${ }^{4}$ This treatise shows that "the girih mode was conceived of as a system of proportionally related geometric patterns harmoniously interlocking with one another" (Necipoğlu et al. 1995:133) and also provides descriptions of how to draw patterns, and in a few examples demonstrates the use of

\footnotetext{
${ }^{3}$ I am grateful to Prof. Reza Sarhangi for these observations.

${ }^{4}$ Necipoğlu's study of the hand-written ms. Persan 169 in the Bibliotheque Nationale de France in Paris (2016) suggests that this is a copy of an original version, as the drawings do not have un-inked lines in their execution.
} 


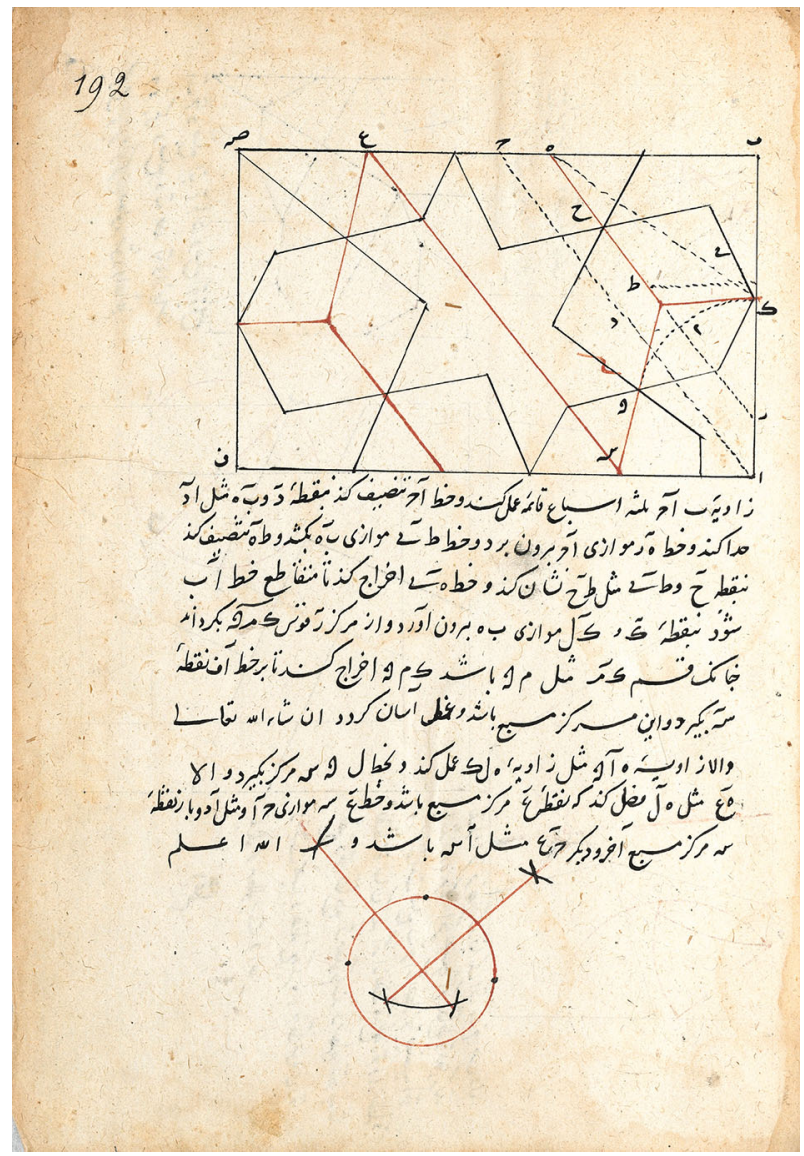

Fig. 3 Page from Fì tadākhul al-ashkāl al-mutashābiha aw al-mutawāfiqa explaining execution of the girih in Persia circa the tenth to thirteenth centuries. Bibliotheque Nationale de France, Ms. Persan 169, fol. 192

the drawing tool in executing the drawing itself. These drawings, while alluding to building ornamentation and craftsmanship described by Buzjani, are more abstract and communicate the fundamentals of the use of practical geometry.

In the early Islamic era, according to al-Farabi's classification of sciences (alFarabi 1985), architecture was situated in the field of practical geometry. This is also an era where the boundaries between fields of sciences and crafts are not established. Therefore, workers of the field of architecture followed principles and guidelines handed down by mathematicians. Design drawings of this era were geometric explorations for two-dimensional revetments, and on some occasions, provided suggestions for three-dimensional spaces of muqarnas. This intellectual tradition informs drawings from later centuries with the extensive and elaborate use of use of patterns for two-dimensional revetments and three-dimensional spaces. However, later surviving drawings also document the emergence of plan drawing as 


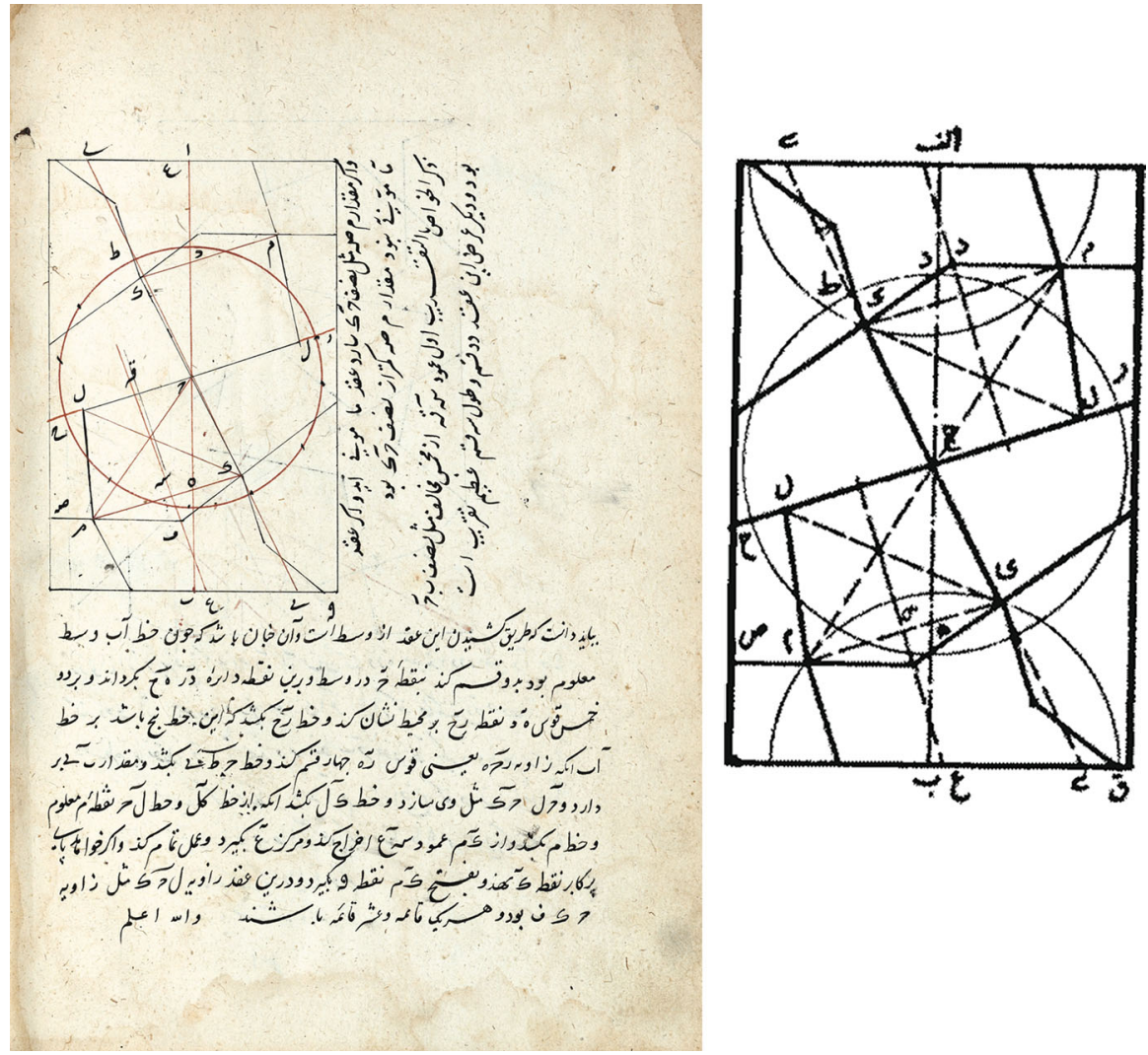

Fig. 4 Left Page from $F \bar{\imath}$ tadākhul al-ashkāl al-mutashābiha aw al-mutawāfiqa explaining execution of the girih in Persia circa the tenth to thirteenth centuries. Bibliotheque Nationale de France, Ms. Persan 169 , fol. $193 \mathrm{v}$; right reconstruction of the geometric drawing

an exclusive form of geometric drawings used by architects, autonomous from the tradition of practical geometry.

\section{A Classification of Architectural Drawings}

The process of conceiving a building at the design stage remains somewhat shrouded in the absence of a comprehensive understanding of role and means of the architect in the pre-modern Islamic world. As mentioned, it is not clear whether a single person took charge of the design or the design was an outcome of a group collaborative effort. Arash Etemad Yousefi indicates that "Timurid sources suggest that boundaries between the tasks of various workers in the field of architecture were not as concretely established as contemporary models imply and, that the participation of a large group of individuals including craftsmen, patrons, and even 
official superintendents were often integrated in the process of design" (Yousefi 2005: 30). This makes even harder to understand the role of the drawing in guiding the conception of buildings. Limited research exists on the history and theoretical genesis of architectural drawings in the Islamic world. ${ }^{5}$

Studies on classifying geometric patterns have yet to provide a comprehensive framework as to how a building was envisioned and designed. Rempel studied Tashkent scrolls (ca. fifteenth century) and classified various types of drawings (Rempel 1961). Gülru Necipoğlu has pursued a similar approach and classifies Topkapi scroll drawings (ca. sixteenth century) in a way that is close to that of Rempel. Necipoğlu created a classification of the geometric mode of girih, which is mainly based on the prior work of (Rempel 1961). Together, their studies provide a classification for geometric patterns based on two sets of drawings. These classifications are typological in nature, associated with the design of ornaments in two-dimensional and three-dimensional appurtenances. Both classifications identified various types of girih modes based on checkered system, radial system, or star-and-polygon, etc., but neither discusses spatial implications or association with the process of erecting buildings.

My classification here is different, and is intended to provide a different focus on the role of drawings in the making of buildings. This divergence is, in part, due to a broader view of drawings in Islamic architecture, which is not limited to ornaments, as well as associating architectural achievements with design thinking and imagination. The present classification attempts to theorize a framework on modes of design thinking, represented by respective drawings, and spatial configurations of buildings. This framework can simply complement the existing typologies, which are captured through a historiographical lens. Discussions will follow to show how the framework relates to the philosophical underpinnings that influenced the realm of mathematics and geometry.

With mathematics and geometry becoming highly regarded sciences for their accuracy and association with important philosophical concepts of their time, architectural design also carried transcendental values due to its geometrical embodiment. Such mystical interpretation was also emphasized and well-articulated by numerous thinkers and philosophers. From the Ikhwan al-Safa's tenth-century comparisons of geometry with celestial orders that re-interpreted Pythagoras's teachings (Ikhwan al-Safa 1978), to Ibn Arabi's mystic analogies of creation and geometry, as well as his interpretations of the human body and its "centrifugal" movements, all contributed to a conscious practice of envisioning and designing architecture through geometry in relation to the cardinal movement according to the human body.

It is in this context that I will investigate the triplicity of geometric drawings corresponding to both physical and figural views: downward-looking plan drawings,

\footnotetext{
5 Some literature exists on the ornamentation and geometric pattern in Islamic art and architecture, however, most of them either on historic documentation, typology, or semantic studies of these geometric patterns. The body of work of Gülru Necipoğlu in this area can be viewed as the major and most complete study of history and to some extend theories of architectural representation in the Islamic world.
} 
outward-looking two-dimensional drawings (girih patterns, ornaments), and upwardlooking three-dimensional drawings (muqarnas, reflected ceiling plans). ${ }^{6}$ In the following sections, each of these modes of geometric drawings will be discussed, including an examination of the relevant philosophical underpinnings, as well as the technical utility each of these modes that provided prompts to the "design thinking" of the time.

\section{Downward Looking: Squared Grid Systems of Plan Drawings}

Al-Ghazali mentions the tradition of drawing building plans in the eleventh century; however, the earliest surviving plans date back to the fifteenth century and are associated with the eastern Islamic world. Consistent among these plans is a squared grid system on which the drawings were executed. These plan drawings do not show a sophisticated level of detail; rather, they communicate basic information, such as where the walls and columns are intended to be. The use of a grid suggests a relationship between a grid unit on paper and a specific number of bricks.

Typically, checkered grids of $8-10 \mathrm{~mm}$ were constructed by a stylus as un-inked lines (or dead-lines) on the surface of the paper. In one early Ottoman drawing, details of doors, lattice windows, and reflected ceiling are also shown, which was somewhat rare for that period and those that followed. In this drawing,"the paper was prepared with a blind grid of squares measuring 8 square $\mathrm{mm}$ on which the plan is drawn in black ink, with the thickness of walls colored red. Its representational conventions consist of domes drawn with a compass, crossed window lattices, and parallel semicircles indicating gate arch" (Necipoğlu 1986: 231). Another related drawing does not show an un-inked grid; however, crossed dead-lines in rooms and rectangular spaces could imply a system of creating proportioned spaces based on an initial grid line. ${ }^{7}$ The surviving drawings of Tashkent Scrolls from the sixteenth century also include checkered grids to conceive plans of buildings (Fig. 5). The grid provided the architect with a comprehensible modular tool for construction, which was also useful for cost estimation. Donald Wilber mentioned that during the Safavid period (1501-1722), cost estimation of construction was assessed based on the thickness and height of building walls. Each square unit of the grid would correspond to a certain number of bricks (Golombek et al. 1988). For an experienced master, this number represented an index of building materials and most likely an estimate of time for the completion of the edifice. The relatively

\footnotetext{
6 I understand that my categories here could be arguable. However, my motive is to distinguish the drawings in association with architectural conceptions during in the design process; two-dimensionalplanes and threedimensional spaces. Necipoğlu's classification also recognizes this distinction; however, he did not put plan drawings under the category of three-dimensional. A plan drawing, while seeminglysimpler in construction based on a checker system functions the same as a muqarnas, in the sense theyboth denote spatial depth that is not shown in the drawing. I am aware that one can find other alternativesto classify these drawings. There are, however, some drawings that have been eliminated in myclassification, for example the last drawing of the Topkapi scroll with vegetal drawings (see Necipoğlu et al. 1995, Cat. No. 114). The reason for that is due on the one hand to theconcentration on the abstract geometric mode, and on the other to the negligible quantity of such vegetaldrawings in extant historical drawings.

7 This possibility was indicated in (Necipoğlu 1986).
} 
Fig. 5 Plan of a caravanserai or madrasa from the Tashkent scroll, sixteenth century, Drawing attributed to an Uzbek master builder. Institute for Oriental Studies, Uzbek Academy of Sciences. Also published in (Necipoğlu et al. 1995:8)

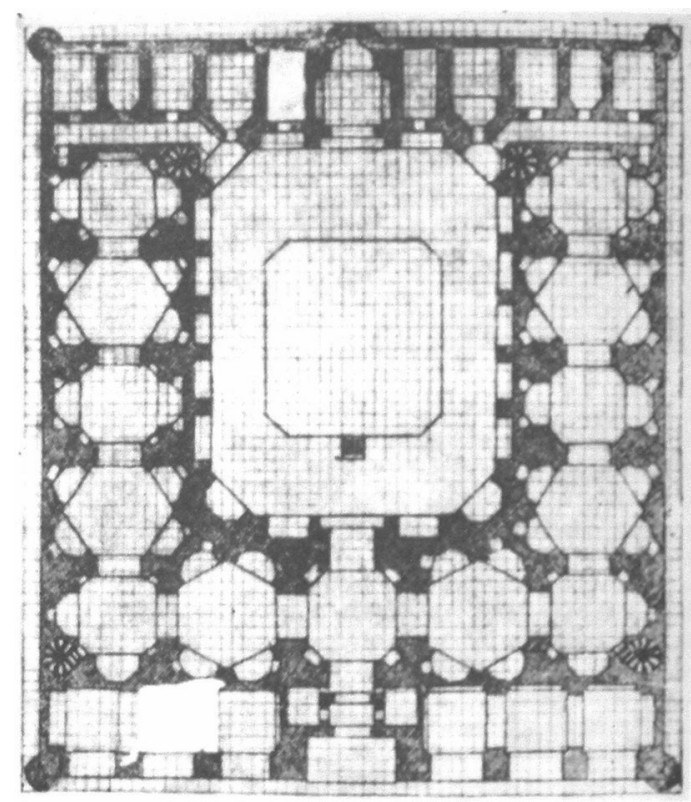

simple plan drawings when compared to the detailed, large scale girih drawings can be better understood by the relative importance of a building's final finishing details. Plan drawings by Mirza Akbar, a nineteenth- century Royal Qajar architect, also utilize a similar grid system and show the plan in rough and undetailed fashion (Figs. 6, 7). It appears that gridded plan drawings were in continuous use from the fifteenth century up to the time of Mirza Akbar. A late nineteenth- and early twentieth-century architectural terminology popular among Iranian master masons could provide glimpses to the relationship between plan drawing and geometric ornamentations. Asqar Sha'rbaf, a contemporary Iranian master mason, was also a traditional architect whose heritage extends from a family of masons who have practiced since the eighteenth century. Sha'rbaf, recalling terminologies from the past, distinguishes building construction in terms of two complementary parts: body or mass (haykal) and essence or ornate (jowhar) (Sha'rbaf 2006). He considers jowhar as principal, which he argues is revealed in the three-dimensional geometric patterns of an edifice (Pournader 2000). ${ }^{8}$ Considering that his use of such concepts

\footnotetext{
${ }^{8}$ In this regard, Pournader mentions a visit to a mosque in Tehran with Asqar Sha'rbaf. When asked to interpret the inscription installed below brick muqarnas of the entrance of Imam Hossein mosque, Tehran, indicating: "Tell who is the designer and architect of this mosque? Master Muhammad [architect-engineer of the mosque]...". When asked, "Who is Muhammad? That of in the building or in the ornamental patterns?", Asghar Sha'rbaf repled, "The mosque itself is but a big mass (haykal), Muhammad is more in the geometric patterns (kar bandi)" (Pournader 2000: 48; my trans.). His response indicated that master Muhammad's fine work is found in the geometric patterns.
} 
Fig. 6 Plan drawing based on grid system, late eighteenth century, Iran. The plan represents a lower level of sophistication compared to fifteenth- and sixteenth-century Ottoman plan drawings.

Courtesy of Victoria and Albert Museum, London

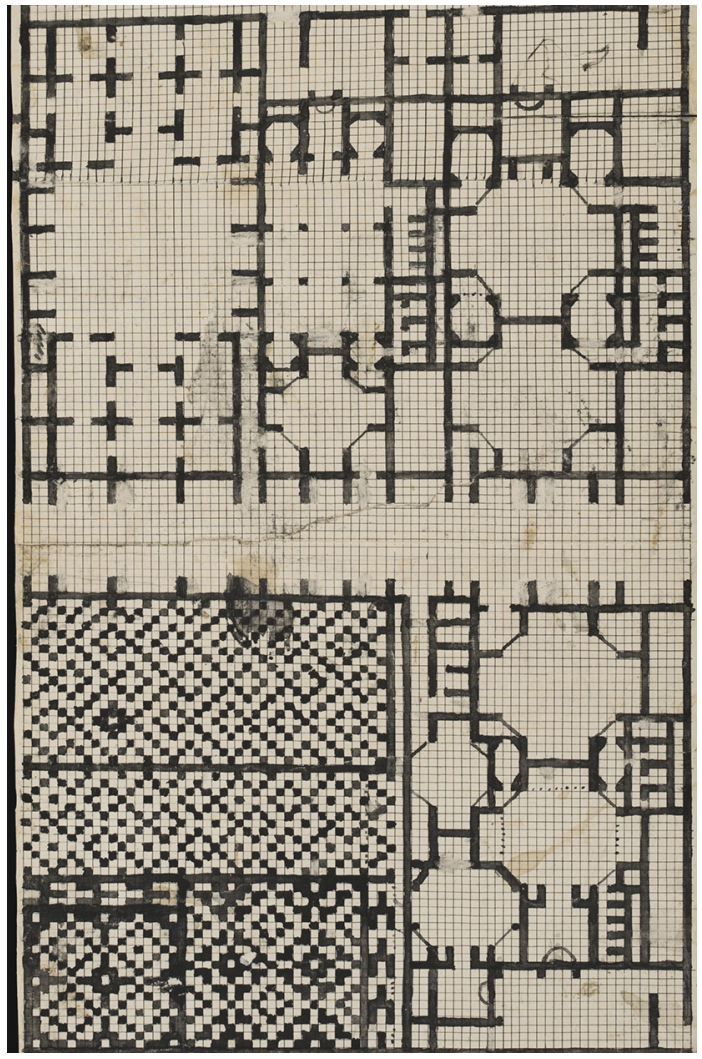

dates back to the eighteenth century, we can assume that architects of the past held a similar notion regarding the primacy of the final ornamentation over the building mass when they were conceiving architectural plans.

The existing plan drawings are rather unsophisticated representations that capture the rough body of the building. ${ }^{9}$ With such basic plans in hand the architectsengineers were likely able to envision spaces for ornaments on walls, and geometry of vaults, half-vaults above the plan. Nevertheless, these plans did not really provide an accurate representation of the final edifice, which would be completed with the

\footnotetext{
${ }^{9}$ Ottoman drawings represent more sophisticated plans. It is believed that Ottoman architects possibly had contact with Western architects of the time, as evidenced in Necipoğlu's observation: "The plan of an imperial mosque and later Ottoman examples from the sixteenth century ... are characterized by a unique set of conventional signs, such as crossed window lattices, triangular latrines, circular water pipes, bulbshaped furnaces, or parallel semicircles indicating door arches. Their use of some conventions typical of European plans, such as the drawing of arch elevations flat onto elements of a ground plan (characteristic of Western plans prior to 1500), the indication of domes with compass-drawn circles, of columns with circles inscribed in squares, or of steps with parallel lines, seems to imply contacts with European architectural practice" (Necipoğlu 1986: 234). This linkage is supported by the fact that an invitation extended to the Italian architect, Filarete, is mentioned in historical sources, which supports the hypothesis that the sophistication of Ottoman plan drawings was influenced by Western architectural drawing traditions.
} 
Fig. 7 Plan drawing based on grid system, late eighteenth century, Iran. Courtesy of Victoria and Albert Museum, London

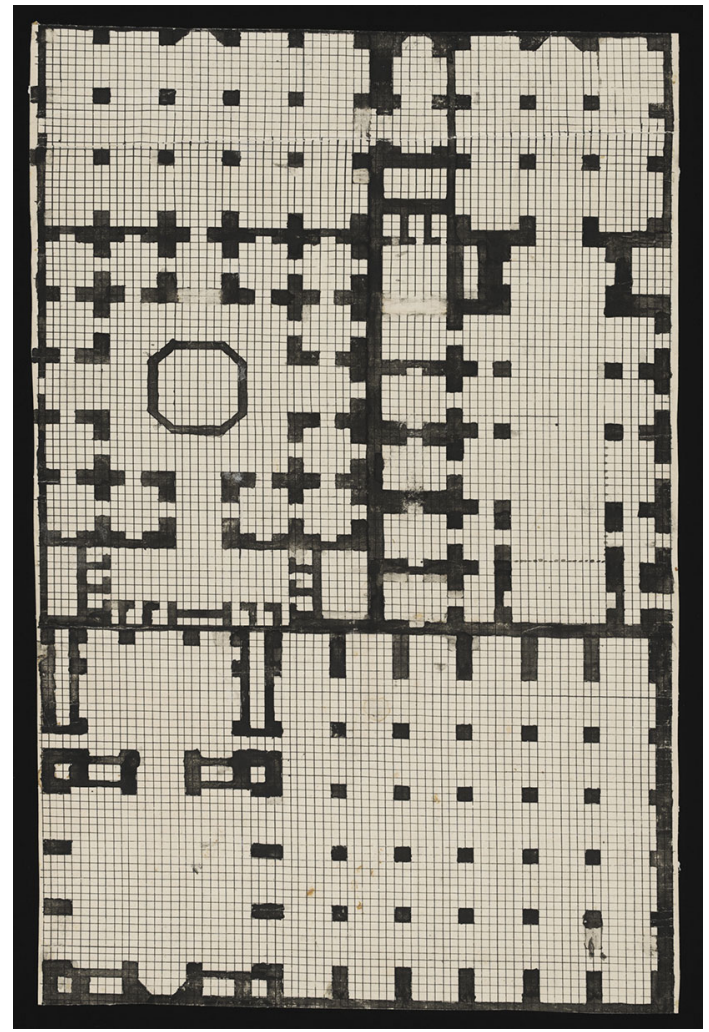

addition of final ornamentations, a notion that has been reported by various early sources such as al-Maqdisi (tenth century) and Ibn Khladun (fourteenth century).

Grid-based plan drawings offered a measuring device, and a quantifiable understanding of the construction. In the Arabic language, the term used for design is qaddara, which comes from the root term q.d.r. and is associated with measuring and numbers. As early as the tenth century such quantifiable features of design were mentioned. The Ikhwan al-Safa mentioned an artisan who designed before commencing his work, and specifically noted that the work needed to have idea, form, and be measured before being built. One of the implications of this concept is that the design refers to quantifiable attributes of the work. By relating each square unit in the grid-based plan drawing to a certain number of bricks, a scalar association between the drawing and the building would be established. In this sense, measurements, materials and work estimations for buildings would be relatively clear at the early stage of a grid-based plan drawing. Indeed, in this process the designer's capacity to envision forthcoming details undrawn and invisible on the plan drawing was critical in successfully completing an edifice with all its details.

The square form and squared grids-widely representing the earthly worldserved as regulating lines to conceive the foundation of the lower parts of a building. 
Such simple geometric drawings involved measurements of the materials and manpower needed to erect a rough and unadorned body of the building. Representing a downward view, plan drawings represented the eyes of the designer (muqaddir) looking below to the terrestrial world, engaging tangible realities such as measurements, the use of materials, and the laying of foundations. The completed form of a building, during this phase, essentially remained in the architect's imagination.

\section{Outward Looking Drawings: Two-dimensional Patterns of Revetments}

This category of drawings was widely utilized in ornamentations on building revetments and played a key role in the final apprearance of a building. Ibn Khladun (1967) recorded one of the first instances of the significance of ornamentation in the fourteenth century. ${ }^{10}$ Several primary sources indicate the significance of twodimensional ornamentations for a building, which would not be considered complete without them. Indeed, these drawings guided construction of these ornaments and considered to be inherent to the design of the building. This category of drawings relate to two-dimensional patterns and ornaments and, typologically, can be divided into three different sub-categories: drawings that utilize a checkered grid, drawings that utilize trigangular/hexagonal grid, and drawings with radial grids (Necipoğlu et al. 1995).

\section{Checkered Grid Ornamental Drawings}

In the first sub-category, checkered geometric drawings are used to compose calligraphic brick tiling, khat-i bannai (literally, masonry calligraphy) for surfaces. These geometric shapes can be filled with different colors, or may remain unadorned (Fig. 8). While Necipoğlu's broad definition of girih would include these geometric patterns as well, there is no consensus with regard to situating this category of constructs within the girih mode. These drawings communicate inscriptions into the building ornamentation in linear, symmetrical, or rotation fashion. They maintain a direct relationship with the final built object.

\section{Trigangular/hexagonal Grid Drawings}

The second sub-category corresponds to outward-looking drawings that are based on triangular grid-based drawings. In the case of an equilateral triangular grid, they can suggest centralized forms, but rarely imply a three-dimensional space (Fig. 9). With no precedent for executing architectural drawings in such isometric projections, however, it remains unclear whether the intent of creating cubic-like ornaments was a three-dimensional interpretation of the detail or not. The inked

\footnotetext{
${ }^{10}$ Ibn Khaldun sees the necessity of the craft of architecture for making a shelter, but he distinguishes between those who care for their buildings and those who do not, as the former group "make their walls of stones, which they join together with quicklime. They cover them with paint and plaster and do the utmost to furnish and decorate everything in order to show how they are concerned for their shelter" (1967: 320).
} 


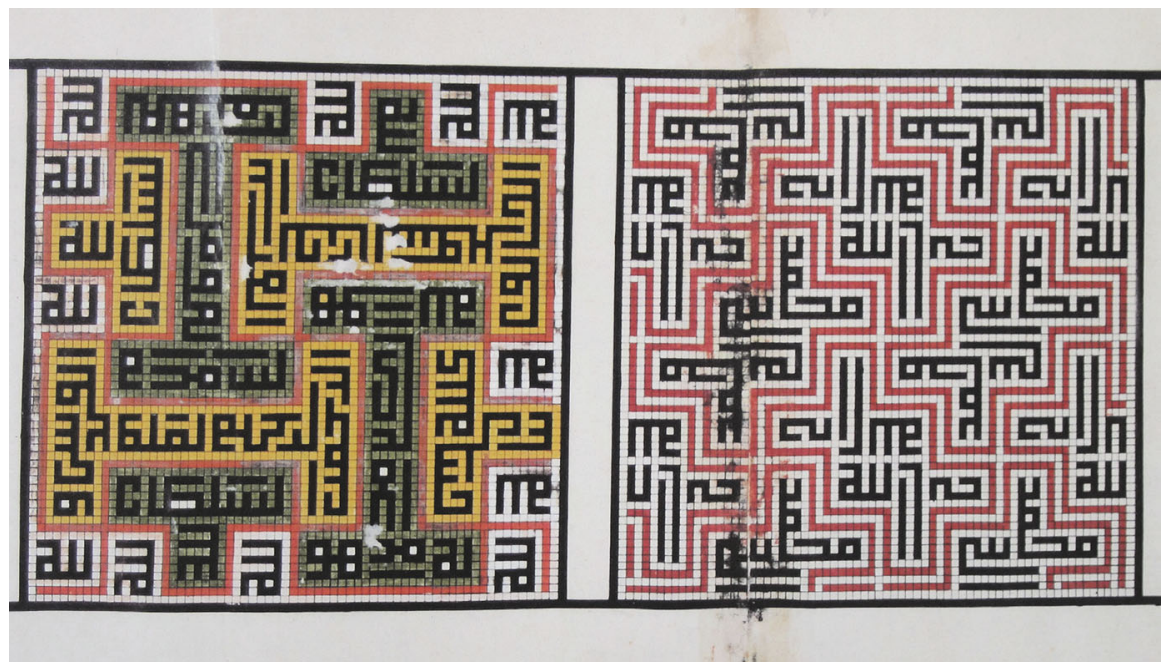

Fig. 8 Geometric drawing from the Topkapi Scroll representing a two-dimensional patterns of inscriptions. This type of pattern is used to ornate revetments with glazed bricks. Topkapi Museum Palace. Image: Public domain

Fig. 9 Geometric drawing using triangular grid inscribing words Ali (center) and Muhammad (perimeter). Topkapi Museum Palace. Image: Public domain

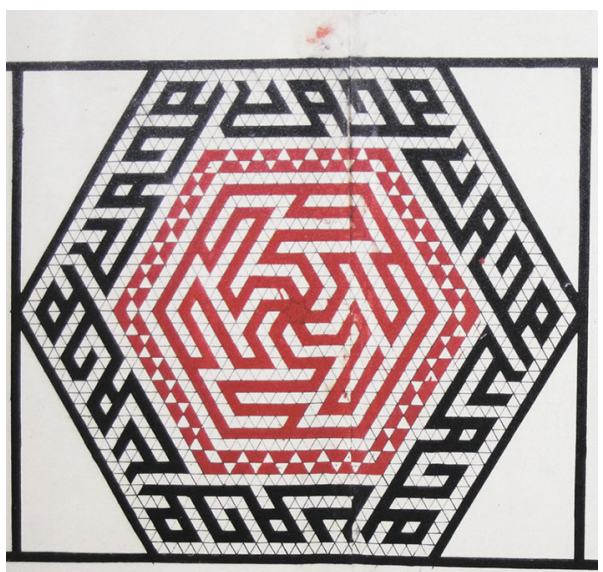

grids correspond to colored glazed bricks, and the lines of the grids accord to the joints. In these drawings, the construction lines match the final drawing.

\section{Radial Grid Drawings}

The third group of geometric drawings can be recognized by their composite radial construction grids (Fig. 10). Uniformly accepted as girih by all authors, in this category of drawings the construction lines and the final drawings do not correspond 


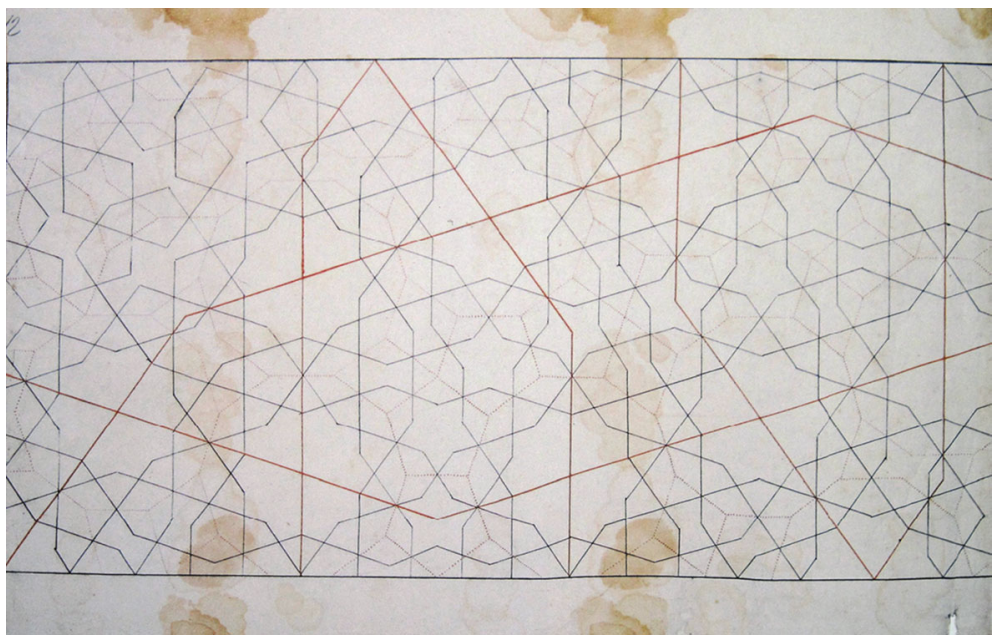

Fig. 10 A drawing from the Topkapi Scroll showing a star-and-polygon pattern representing a sophisticated girih mode. Topkapi Palace Museum. Image: Public domain

to each other formally, but are instead viewed as two separate layers. Executed through the use of compass and straightedge, the construction layer comprises circles with radii projecting from the centers. The intersection of the radii with circles is used to create the final girih pattern. The geometric pattern is a result of connecting these intersections. In other words, the only literal overlap of the two layers of construction lines and drawing lines are some nodes. These nodes relate the invisible and visible layers of the drawing.

Within a rectangular or square frame corresponding to their repeat unit, the execution of these drawings suggests an order: a radial move from the corner of the repeat unit towards the interior. The final inked drawing, however, does not follow the order of the construction lines. Since the final pattern holds homogeneity, the pattern is potentially capable of expanding in all four planar directions. These patterns culminate in star-and-polygon girih patterns. Necipoğlu and Rempel detected other subcategories for such patterns; however, since this paper is concerned with spatial implications of the drawing, it will not investigate those subcategories here. The expanded final pattern implies larger orbit-like circles, similar to the string of a necklace, passing through a variety of shapes. Perceptually, one's eye can constantly rove from one orbit to another. With a collection of orbits, the visual experience could potentially exceed our monocular vision and enter a realm of polycularity. ${ }^{11}$

Additionally, the layer of the un-inked lines played an intellectual role, it was in this invisible layer that the foundation of visible forms, measures, and proportions were all conceived, calling for the use of precision drawings tools such as compass and straightedge. The compass, its point analogous to the center of the world, served

11 This experience could move the viewer away from a bodily visual experience and invite him or her to exceed monocular vision and experience a realm of polycular sight, which is an imaginative experience linking the viewer to the potential cosmic attributes of the pattern. 
as the generative agent in the creation of invisible construction lines of the drawing. The final visible patterns and shapes were outcomes of the invisible geometric configuration. The stage between the two-the invisible and visible geometries-is a thought-provoking level. It is a level wherein the drawing and the drawer moved from an invisible structure to a visible world; certain lines had to be inked, others left un-inked. ${ }^{12}$ This intermediary stage is also analogous to an "epistemological quest", in geometrical terms. Together with the final inked drawing, the interwoven layers of invisible (un-inked construction lines) and visible (inked girih pattern) represent an in-between state of being, offering an ontological realm, and suggesting creative linkages between unseen ideas and seen things (Fig. 11).

With the increasing use of geometric patterns by the eighteenth century, the process of designing and achieving patterns had already become a well-ingrained skill among master masons, and it is likely that the patterns were memorized as master templates. This transition is evident in the drawings of Mirza Akbar, where there is little indication of the use of construction lines in his drawings. Additionally, master masons discovered "secret" auxiliary geometric skills in conceiving girih. This "secrecy" is evident in the drawing processes of Master Lorzadeh (1906-2004), one of the last of his generation with a link to eighteenth-century traditions of master builders. In his book (2010), Lorzadeh describes ways of drawing various girihs, starting from the rectangular frame (repeat unit), and then drawing a circle and projecting radii lines. A "secret line" (khat-i ramz) is then added to cut the radii in order to find key intersecting nodes to create the ideal pattern (Fig. 12). ${ }^{13}$

Most of these two-dimensional drawings were realized in vertical revetments. While the previous category, plan drawings, dealt with a "downward" view, this category refers to a "frontward," or "face-to-face" view, an encounter that is directly experienced as a window. These two-dimensional drawings adorned the "absent" vertical surfaces in plans. The grid in the plan drawings would create a modular system to accommodate a wide range of ornaments on vertical surfaces.

\section{Upward-Looking Drawings: Three-Dimensional Patterns of Vaults and Domes, and Reflected Ceiling Plans}

Geometric drawings addressing the space "above" are the most sophisticated and eloquent. These drawings represent a variety of spatial geometric constructions, culminating in muqarnas and vault structures (Fig. 13). In contemporary terms, we categorize such drawings as the "reflected ceiling plan." However, it is unclear whether practitioners of the time shared this view. Although conceived as threedimensional embellishments, these stalactite structures were drawn in a planar mode. This made both the conceiving and construction process for these structures

\footnotetext{
12 The tradition of using dead lines was gradually supplanted by the contemporary use of blue lines and guidelines in contemporary architectural practice. There are still many similarities between them in terms of how the final drawing comes into existence and how the architect is engaged in an intermediary stage of giving birth to the final drawing. The constant move from the light blue/gray drawings and the emerging drawing is a move from two stages of being-one pertaining to a more intelligible one and the other to a more tangible world.
} 

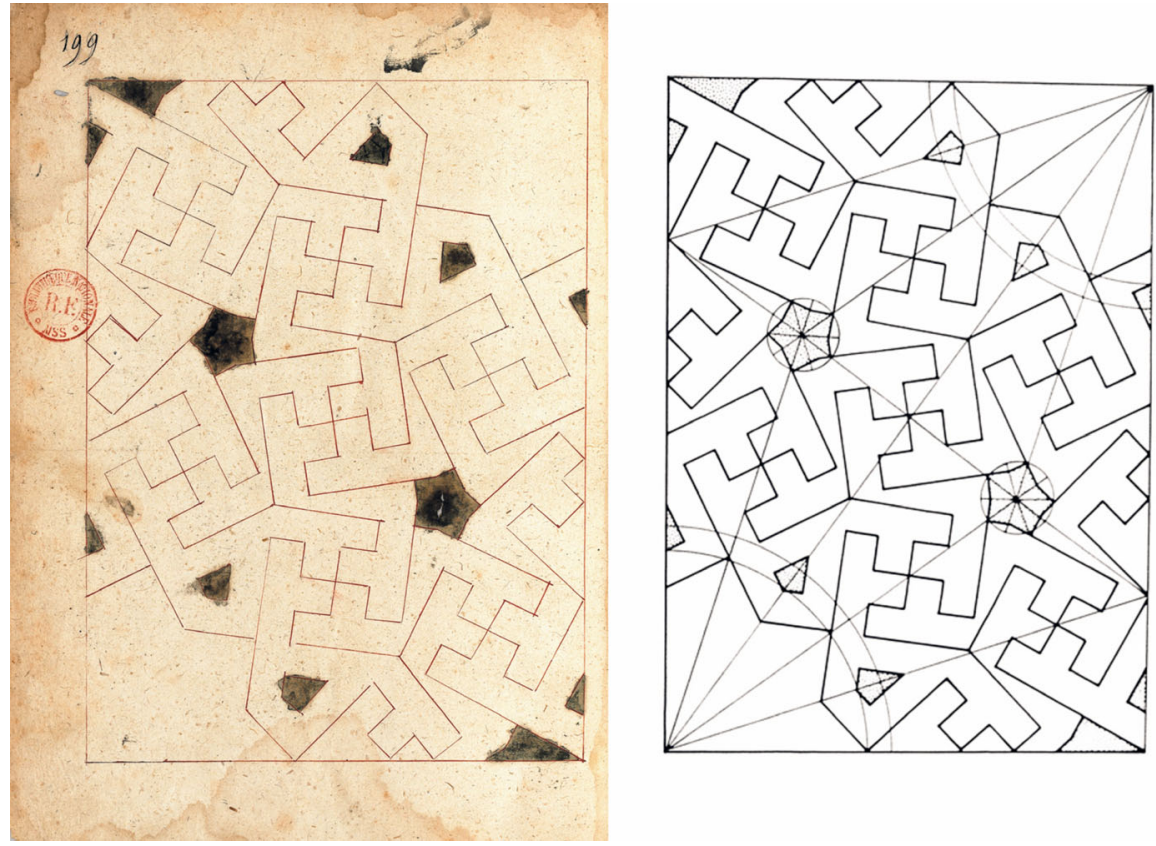

Fig. 11 Left Folio from Buzjani's appendix, eleventh -thirteenth century? Right diagram of un-inked construction lines as circles and radii. The invisible construction lines of the girih pattern represent a different geometry from the final inked pattern. The circle structure can also be imagined/seen while one gazes at the pattern. In this sense, they function as imaginal orbits constantly moving the eyes from one center to another. That is how girih succeeds in taking the human beyond sight perception, which is based on the fixed position of the man in a certain place. Bibliotheque Nationale de France

highly dependent on the talent and artistic taste of the architect. There are two distinguishable sub-categories in these drawings: non-structural three-dimensional drawings, and structural three-dimensional drawings.

\section{Non-Structural Three-dimensional Drawing of Muqarnas}

This drawing category, like the earlier star-and-polygon drawings, is characterized by a repeat unit—namely, half or a quarter of the entire structure. In the case of half vaults, the drawings are mirrored; in the case of full vaults, the drawing is mirrored along its two axes. Necipoğlu's study of construction lines is revealing. Similar to the two-dimensional star-and-polygon patterns, construction of these drawings is "based on dividing concentric circles into equal arcs by equidistant radii, along which rows of polygons and star polygons inscribed in smaller subsidiary systems of circles are formed, the radial grid constitutes the basis of ... three-dimensional geometric designs, including arch-net and muqarnas vault projections. It is often used in conjunction with other grid systems and axes of dynamic symmetry,

\footnotetext{
13 Maheronnaqsh (1984) also provides solution for the geometric construction of the same pattern. For a detailed explanation see (Sarhangi 2012).
} 

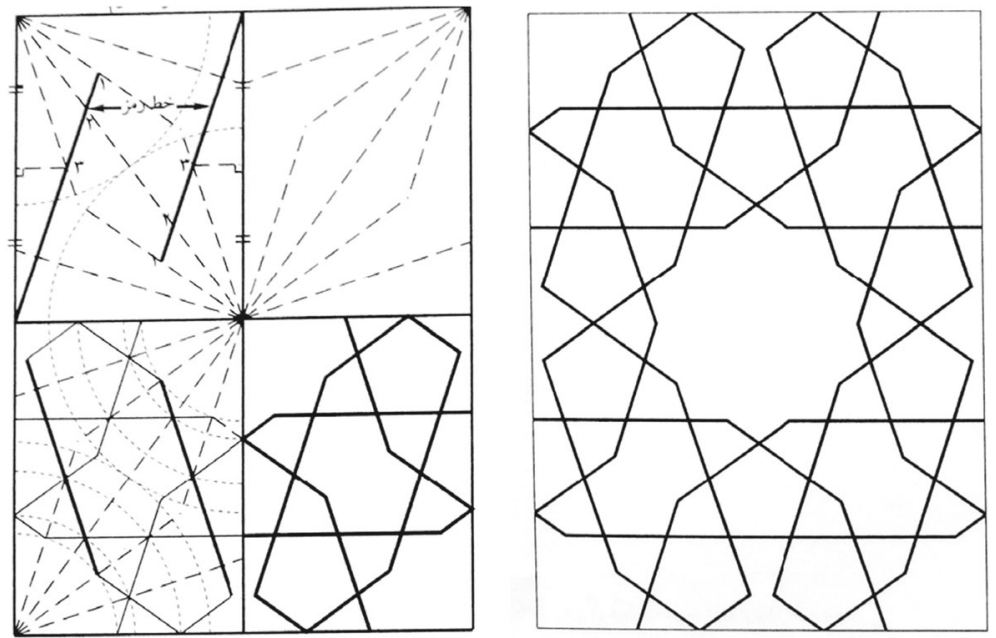

Fig. 12 Example of drawing process of a girih by Lorzadeh. Left shows the process starting with two "secret lines" crossing projected radii (upper left quadrant). The drawing is also based on the concept of the repeat unit, a quadrant of the complete pattern. Image: (Lorzadeh 2010)

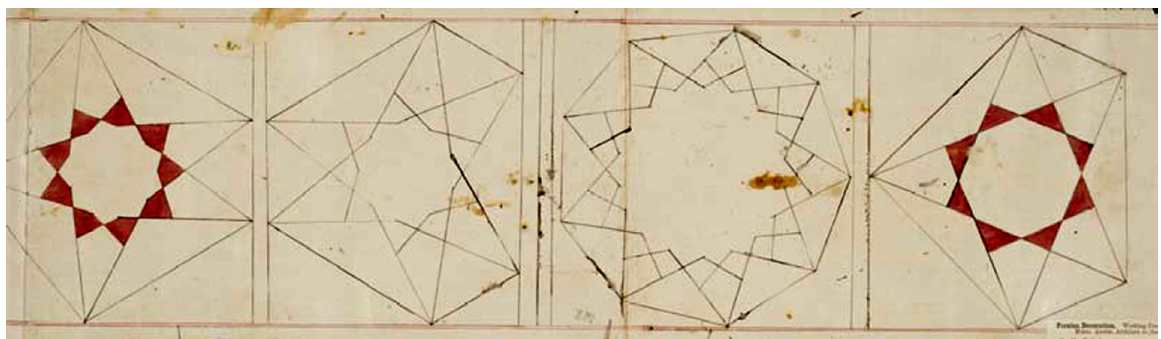

Fig. 13 Reflected ceiling drawings of vaults and domical spaces from Mirza Akbar scroll drawings, late eighteenth century, Iran. Courtesy of Victoria and Albert Museum, London

resulting in composite networks of uninked 'dead' drawings that generate complex multi layered patterns" (Necipoğlu et al. 1995: 13). Un-inked construction drawings provide a structure for the final pattern. In comparing the invisible construction lines with the final formal appearance of the geometric pattern, one sometimes finds a radically different order (Fig. 14). Additionally, with a one-plan drawing a variety of spatial projections are expected, depending on the height of the vertical surfaces to be covered. ${ }^{14}$ This suggests a third layer of geometry involving construction processes that addressed volumetric geometry (such as vertical lines) and geometric

\footnotetext{
${ }^{14}$ Necipoğlu discusses the multiplicity of translating planar and spatial projections as such: "The direct translatability between planar and spatial geometry, based on a limited number of geometric progressions allowing a wide range of variation, contributed to the sense of unity in Timurid architecture and its surface decoration, reflecting an intimate relationship between the principles of architectural design and ornament" (Necipoğlu et al. 1995: 13).
} 

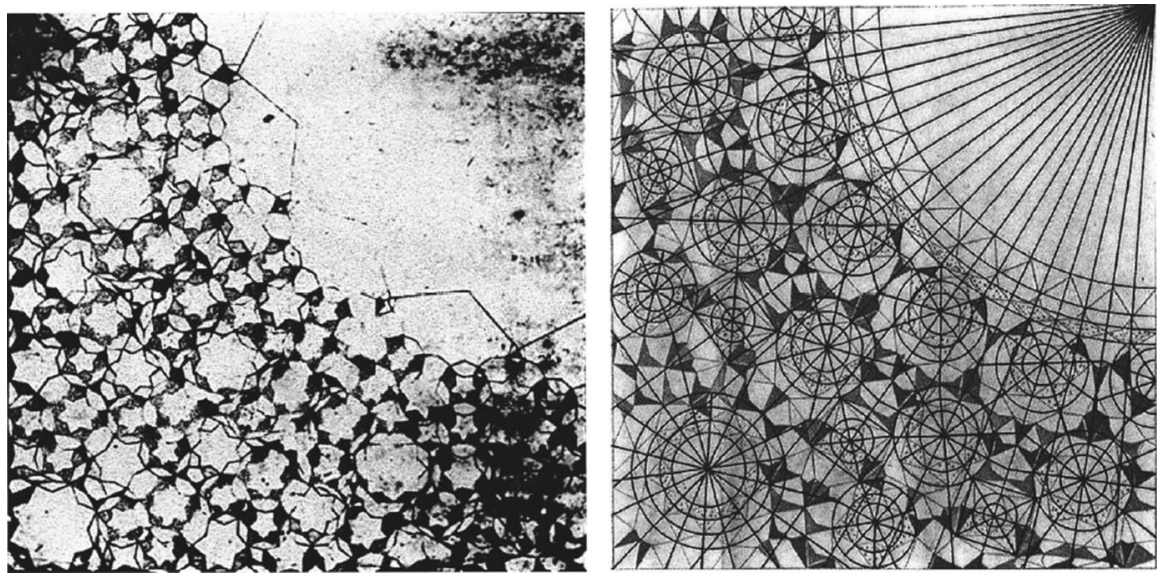

Fig. 14 Left Drawing of half or quadrant of a vaulted muqarnas from the Tashkent Scroll, sixteenth century. Right overlaid diagram showing the construction un-inked lines of the muqarnas based on the circle structure (i.e., projected radii and arcs). The underlying orbit-like structure along with stellate-like patterns, makes the muqarnas analogous to the macrocosm cosmological space of orbits and stars. Courtesy Institute for Oriental Studies, Uzbek Academy of Sciences. Image: (Yousefi 2005)

lines of transferring drawing into construction (such as plumb lines). ${ }^{15}$ Once the drawing (i.e., dotted lines of charcoal) was transferred onto the plaster of Paris, each layer and step were cut. Then by means of a plumb line, the plan was transferred to the space above to determine the accurate placement of each layer (Fig. 15). Therefore, the process of constructing a muqarnas involved two drawing stages: the first on a small-size paper with no scalar relationship to the envisioned finished product, and the second in full scale on the floor directly below the "future structure." The full-scale drawing was almost a re-drawing of an initial formal idea, since the "ideal" pattern on preserved scrolls did not necessarily match the proportionality of the construction job. In this sense, the transformation of the ideal pattern into an approximation of the larger scale involved the imaginative participation of the architect, an in-between level between Reason and Sense.The craft of approximating an ideal pattern to certain actual sizes and proportions belongs to the class of science known as hiyal. This act of approximation and fitting

\footnotetext{
15 The muqarnas geometric drawings were augmented by full-scale drawings at the construction site. The stalactite structure is comprised of horizontal levels. The floor of the area above which the muqarnas was planned to be fabricated, was used to pour plaster of Paris in layers about an inch thick. Then, the plan of the muqarnas was drawn on a thin sheet of the hardened mold. The transfer of the drawing from the full scale drawing on paper onto the plaster was handled through the use of pin-punched paper that allowed charcoal powder to pass through it. The powdery trace drawing was called hayula. The conventional use of the term is translated as "monster," which could refer to the intermediary nature of this stage of drawing, in the sense it is was composed of a variety of materials and processes, but was still not fully realized. Marco Frascari (1991) discussed in detail the notion of monster and its significance for design thinking. In philosophical terms, hayula was "shapeless substance." The term hayula is adopted from the Greek/Latin term hyle, and is particularly associated with the Aristotelian notion of matter, or cause of matter. This intermediary presence (a matter without form) also accords with the intermediary stage of translating the geometry into construction.
} 

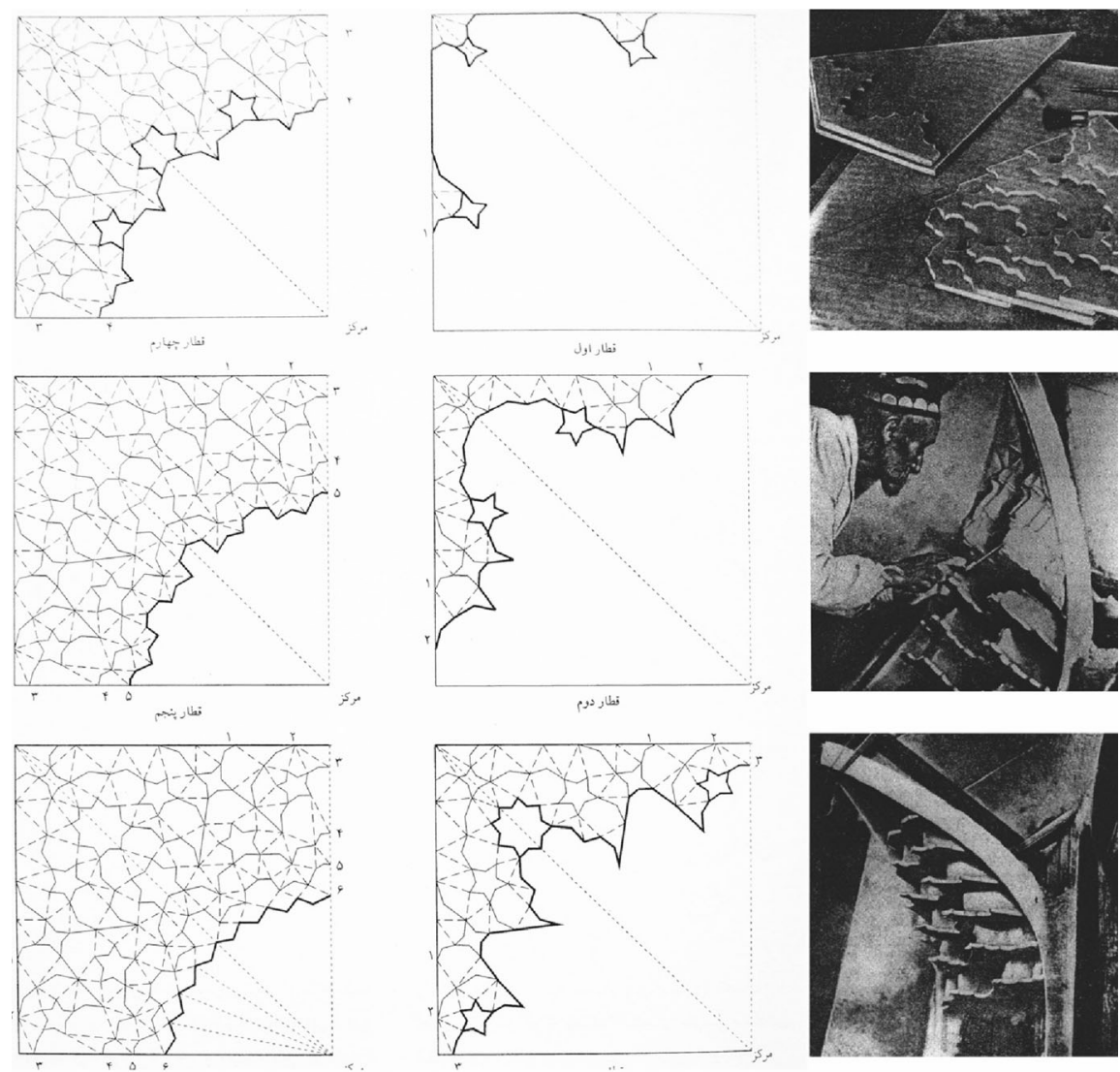

Fig. 15 Left Process of drawing a muqarnas by Lorzadeh. The drawings are based on the concept of repeat unit and demonstrate half of the vault. Each stage demonstrates one horizontal layer of muqarnas structure. Image: (Lorzadeh 2010). Right The construction of muqarnas involves creating horizontal shelves (layers) and the vertical dimensions are determined by the dimension and vertical proportion of the vault structure. Image: (Yousefi 2005)

an ideal pattern to the confines of the reality is expressed by Muhammad Sha'rbaf when he refers to a drawing during a conversation with his son, Asghar Sha'rbaf: "You see this drawing, ... but I see that corner ... I see that how many times this drawing has changed dresses until it corresponds [properly] to that corner" (Pournader 2000: 46, my trans.). By having some ideal patterns in mind (and perhaps in his own preserved scrolls), the old master was referring to the shrewd intelligence of the architect in carefully negotiating some ideal pattern within the actual restrictions of a corner of an existing wall. The process of materialization also entailed another intermediary stage of the use of pin-punched paper, called gardih (literally, powder) paper. This intermediate level is less material than the drawing on the plaster of Paris, but more material than the abstract ideal patterns preserved in the scrolls. The lines here are dotted punches (voids with no matter) allowing a shapeless substance (charcoal powder) to pass through to cast tangible-materialized 
lines (dots, then read as lines) on the plaster. Additionally, the dotted line is an indication of a line that is there...but is not there, indicating an intermediary state of geometric drawing of dashed line as "something invisible but present" (Emmons 2001). Emmons also discusses the fact that dashed lines are not insignificant technical conventions but contain symbolic meanings, as indicated by Sebastiano Serlio's term linee occulte (dashed line) referring to "secret" and "hidden" portions of geometric solids.

\section{Structural Three-Dimensional Drawings}

A second subcategory of upward-looking drawings is linked to geometric drawings that create vaults and domed spaces and are structural. These structures, often built as a web of ribs, are called kar-bandi (Buzurgmehri 1992). ${ }^{16}$ Based on a radial system, these drawings are constructed from a center projection outward; smaller circles and radii (similar to the original circle) then contribute to the construction of the invisible un-inked structure. Once drawn and completed, it emphasizes star-like geometry. Constructed by a number of concentric orbits, and in a successive diameters, it transforms the lower square shape of the plan to the circular form of the vault. These drawings imply a union of curvature through a basket-like web of intersecting radii.

Linked by these radii, the number of concentric orbits contributed to the intriguing complexity of the vault, which can be best seen in sectional drawings. Drawings by Mirza Akbar are elaborate examples that can be associated with this subcategory of drawings. Buzurgmehri's survey of vaults (in plan and section) shows striking similarities to vault drawings by Mirza Akbar, which are sometimes accompanied by simple section drawings (Fig. 16). However, it is not clear whether all of Mirza Akbar vault drawings showing ribs were intended to be structural. These drawings, while demonstrating a mastery of geometric solutions for transforming rectangular forms into circles, also demonstrate a mastery of a sectional understanding of these structures. The composite radial patterns are upward-looking drawings that transform the lower square structure into the upper circle. These astral drawings are symbolic embodiments of a celestial orders in a terrestrial world. As such, the un-inked projected radii and construction circle drawings can be viewed as critical devices for transforming the terrestrial to the celestial-reflected ceiling plan.

The drawings of the space above, whether muqarnas or kar-bandi, were the most imaginative of all in the sense that the third dimension was always in the designer's imagination and was applied to the drawing during the construction process. The height was determined based both on the real restrictions of the existing vaults, as well as according to the aesthetic judgment of the master builder. The reflected ceiling drawing also suggests that the actual paper would serve as a mirror,

\footnotetext{
16 The Persian terms kar-bandi and rasmi-bandi are used interchangeably and refer to the geometric patterns that transform the cubic space of the lower chamber to the domed space above. In planar view they are confined within rectangular form of the chamber plan, and through the use of triangles the rectangle is transformed into a circle. Rasmi-bandi or kar-bandi are the visible construction lines (rib structures) or merely decorative gypsum lines in the reflected ceiling plan of the vault. Buzurgmihri (1992) distinguishes between the two and identifies kar-bandi as strucutural and rasmi-bandi merely as three-dimensional ornament.
} 


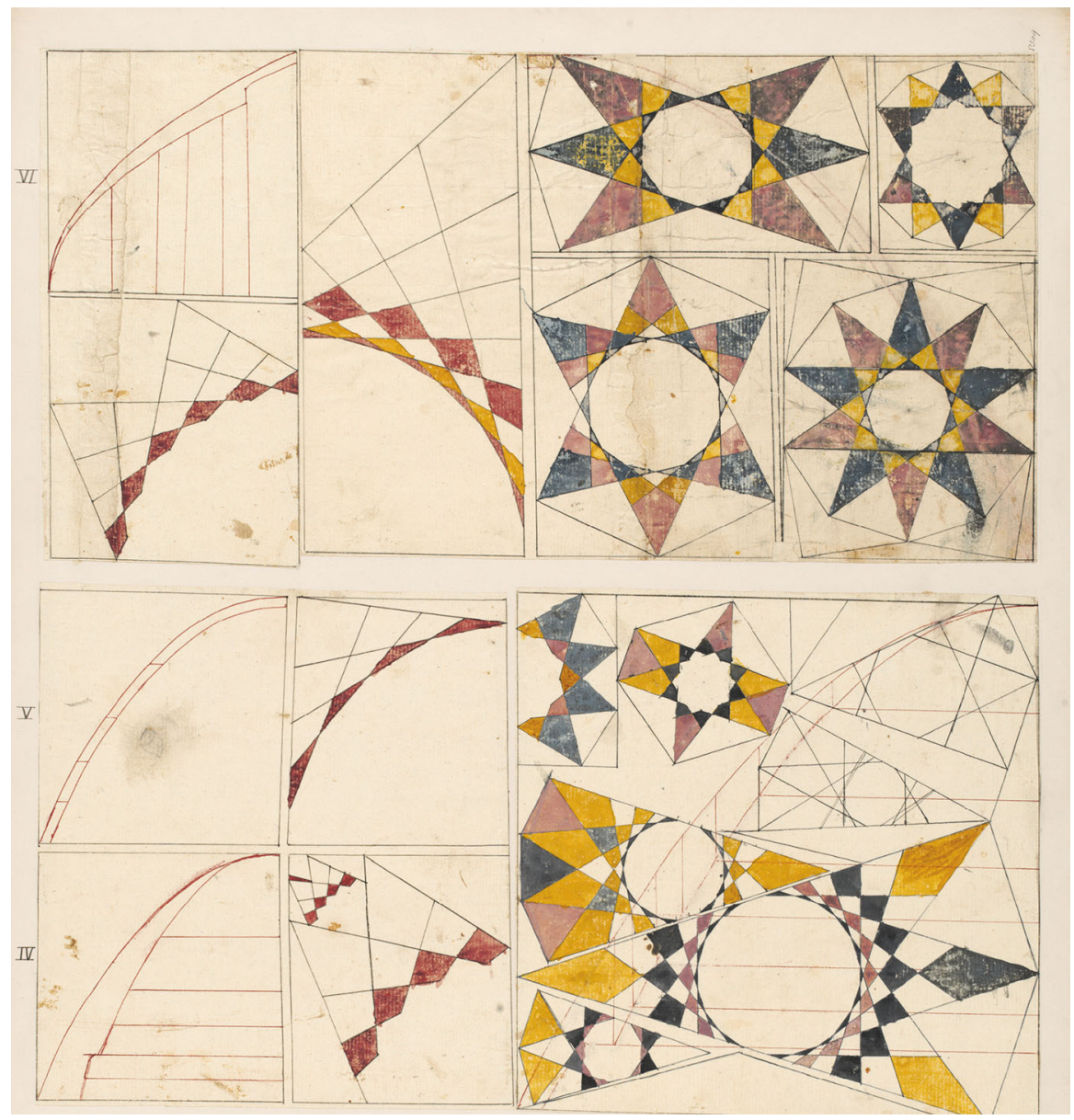

Fig. 16 Plates from Mirza Akbar's drawings of vault structures with kar-bandi, late nineteenth century. Courtesy of Victoria and Albert Museum, London

reflecting the structure to come. This unveiling of beauty, giving rise to a sense of "pleasure and wonderment," 17 directs the mind of the viewer to a realm beyond the material world to one of geometric imagination.

\section{Mnemonic Framework}

The presence of geometry in configuring plans, revetments, and reflected ceiling plans served as a mnemonic device at all levels of geometric conception and execution. Grid-based geometric drawings are perhaps the most striking example of

\footnotetext{
17 This is a reference to Alhazen's note on the experience of beauty in geometry giving rise to a sense of pleasure and wonderment. See (Koliji 2015: 23 and 38-39, notes 103-105).
} 


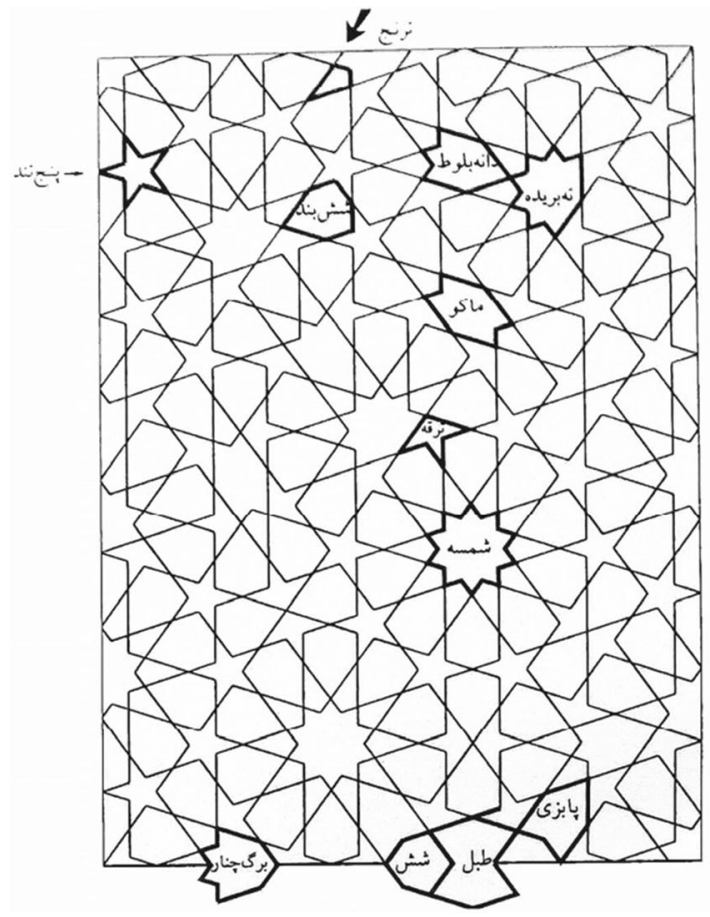

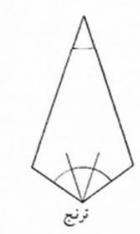
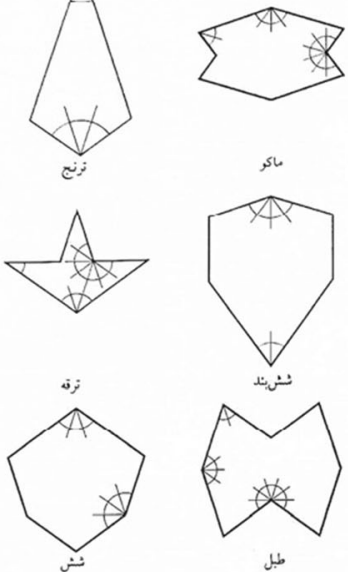

طبل
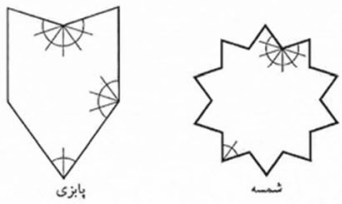

Fig. 17 A collection of named shapes used in girih patterns. Image: (Lorzadeh 2010: 123)

how the architect was reminded of the material quantity and time needed to complete certain portions of the building.

Additionally, in the execution of girih patterns, individual shapes (that is, the elements of the larger visual pattern) carried names. Elemental shapes such as kites create larger figures such as stars. These individual shapes reveal semantic attributes and served as mnemonic devices, since architect-engineers and craftsmen distinguished the individual shapes in girih patterns by name in late eighteenth and nineteenth century Iran. ${ }^{18}$ These forms were used by a variety of craftsmen, including masons, carpenters and tile-makers, who could execute them from memory and with a significant level of expertise. Figure 17 shows some widely used shapes and their associated names within the larger patterns of girih collected by the twentieth-century master builder Lorzadeh.

Moreover, in reviewing surviving drawings one can see that the geometric drawings are usually partial and show a segment of an "overall pattern meant to be multiplied or rotated by symmetry" (Necipoğlu et al. 1995: 10). For example, in the case of vaulted muqarnas structures, the associated drawings are often seen as quadrants or halves to be mirrored or multiplied during the construction phase. Through reconstructing a range of girih patterns, Maheronnaqsh (1984) alludes to

\footnotetext{
18 This is verified through the surviving tradition of girih-making by Lorzadeh and Sha'rbaf, who are from a family of generations of master masons. For further study on this subject see (Lorzadeh 2010) and (Sha'rbaf 2006).
} 
geometric unit in the creation of larger patterns. Isaam El-Said and Ayse Parman (1976) identified the notion of the "repeat unit" at work in the execution of the girih as a fundamental tool for pattern formulation. These unit drawings are geometric components that can be repeated for larger revetments according to their geometric properties. The repeat pattern functions as a generative unit, which, in its repetition, creates a larger, yet different, combination of shapes and lines. El-Said and Parman explained that this fundamental repeat unit is essential for a systematic arrangement of forms to produce an overall design. The notion of the repeat unit also served as a mnemonic device in the conception and execution of overall geometric patterns.

\section{Geometry as Semantic Practice}

Born and cultivated in an era of mystical thought, geometric thinking involved philosophical notions. This linkage is in part due to strong influences of Neoplatonism on the intellectual thoughts of early Islamic philosophers and mathematicians, as well as an increasingly mystic influence of the Islamic world from the fourteenth century onward. Influential thinkers such as the Ikhwan al-Safa, al-Farabi and Ibn Arabi discussed the semantic attributes of geometry and drew parallels with other fields such as music and cosmology. The star-and-polygon patterns carried cosmological attributes, and were therefore able to impart a transcendent sense of beauty.

The Ikhwan al-Safa, making reference to Pythagoras, "who heard the music of the spheres after having been cleansed of the defilement of corporeal appetites and raised to the sublime by constant reflection and by the sciences of arithmetic, geometry, and music" (Ikhwan al-Safa 1978: 57), discussed the purifying role of geometry. Geometry uplifted the mind and the soul to contemplate higher levels of understanding. Similarly, al-Farabi, who considered the formal elements of music as "analogous to the number in arithmetic, the limit in geometry (for example, the arc of a circle, or the side of a square), the syllogism in logic, the strophe in poetry, and the foot in metrics" (al-Farabi, quoted in Necipoğlu et al. 1995: 208), emphasized harmonization (consonance) based on the proportional combination of separate elements, a harmonization that was originally achieved through geometry. Therefore, while al-Farabi did not fully consider all the cosmological dimensions of music, he highly integrated music's beauty into that of the geometric mode. It was in such an intellectual milieu that girih, with its cosmic orbits, linked to other modes of creative activity. In this regard Necipoğlu observes ${ }^{19}$ :

\footnotetext{
19 Necipoğlu also indicates: "Widespread notions about the role of geometry as a bridge between the material and spiritual realms, coupled with the absolute beauty of its harmonious forms capable of purifying the mind like music, must have made geometric abstraction a particularly appealing visual idiom. The purity of a polychromatic abstract design vocabulary dominated by congruent geometric shapes approached the status of light and color, the only two properties that Ibn al-Haytham singled out as being beautiful in themselves in addition to proportionality. This purity of sterilized forms, absolved from impure defilement, no doubt augmented the positive resonances of geometric and geometrized patterns, often accompanied by Koranic inscriptions" (Necipoğlu et al. 1995: 193-194).
} 
... the proportionally interlocking colored geometric forms of girihs that could trigger an innate aesthetic reaction in viewers must have given medieval designers the hope of endowing their visual creations with the expressive potential and emotional immediacy of music. Polychromatic star-and-polygon patterns embodied notions of aesthetic purity and harmony visually aspiring to the music of the spheres. The invisible heavenly orbits of light governing the composition of these patterns can be interpreted as an ambition to raise abstract visual beauty to the same mathematical level as music. Through the use of the circle as a proportioning device, the notion of the music of the spheres found visual expression in girih patterns ....

Just as the consonances of earthly music could strive to echo the heavenly music of the spheres whose transparent bodies emanated light in circular rhythms, so did congruent girihs embody a nostalgic yearning for the pure crystalline structure of the heavens, infused with brilliant light. Their heavenly orientation, betrayed by the insistent use of stars, reflected a wider tendency in Islamic art and architecture to emulate celestial prototypes as models, such as the mansions and gardens of paradise or the Bayt al-Mansur (Prosperous house, the heavenly prototype of the Ka'ba in Mecca) (Necipoğlu et al. 1995: 195).

For the medieval designer, the geometric drawings of girih would have been a contemplative practice that purified the mind and soul. Hence, a subject worthy of investigation is whether such attributes permeated through to the nineteenth century. Through the process of constructing the beautifully proportioned patterns inherent in girih, one could connect to a higher realm of geometry. Such a possibility would have happened first through drawing, then through construction. Interestingly, all these discussions on the semantics applies to the second and third category, and the plan drawings seem to be isolated from such interpretations. This begs the question as how these modes of design drawing/thinking coalesced when conceiving buildings.

\section{Thoughts on the Triplicity of Geometric Projections}

The present classifications of design drawings render the triplicity of modes of design that correspond to fundamental conditions of the building: the geometry of plan, the geometry of wall ornaments, and the geometry of space above. These drawings, in part or in combination, would not render detailed picture of a building, a spatial entity. Unlike descriptive geometry in which the building can be seen as a cohesive volumetric object, the identified drawing categories only provide raw and snipped views of buildings. Questions arise as to how such fragmented conceptions resulted in magnificent buildings.

Additionally, the role and identity of the architect in major parts of Islamic world still begs further clarity. For example, while historical accounts mention a few names of architects, it is hard to spot a sole designer in medieval Islamic architecture. In this period, the practice of design seems to have included a large 
group of individuals. It is likely that through time the role of the architect became more established, and the architects of the courts represented a polymath and master-builder and set the stage for definition of principal designer. Yet it is likely that while the architect coordinated overall issues, other craftsmen also had a say in design. In other words, the design drawings were not as prescriptive as we think of them today.

The gap between the drawing and the construction was always filled with the memory, experience, and improvisations of the master builder and/or craftsmen at work. The gap between these modes of abstract drawings and the realities of the site and construction had to be filled by the designer, whether a single individual or a group. Accordingly, the designer(s) had the burden of pulling together the three seemingly separate geometric views. The building had to be first completed in the designer's imagination. Then the designer's experience and memory played a major role in transforming abstract drawings into tangible built form.

In creating a unified experience of the building, which was achieved through various modes of representational projection, is likely that the designer would establish an epistemological relationship to the drawing distinct from that of contemporary practice. Contemporary design processes are mainly based on descriptive geometry, in which the anticipated object that unifies various orthographic projections is an entity outside the designer. However, in the case of modes of representation in pre-modern Islamic architect, the designer stood at the center and projected geometric representations through cardinal orientations: upward, downward, and outward (front, back, right, left). This model explains the opaque relationship of the projections to the final built form, which became transparent though the hand of the designer completing the work. In a sense, one could argue that these projections were "embodied geometries" that carried spatial attributes, and thus, they can be distinguished from those drawings found in the treatises of practical geometry, where the drawings were merely abstract geometric constructions. While these cardinal movements have immediate associations with the human body, they can imaginatively allude to three kinds of architectural visions in the drawing: downward, outward, and upward.

\section{References}

Al-Farabi, Abu Nasr Muhammad Ibn. 1985. Ihsa al-Ulum (Enumeration of the Sciences, in Farsi). Hussein Khadiv Jam, trans. Tehran: Ilmi va Farhangi Publication Inc..

Buzjani, Abu al-Wafa Muhammad, and Alireza Jazbi. Persian Geometry: Applied Goemtry Abul- Wafa Buzjani (Farsi Translations with Additions). Tehran: Soroush Publications, 2005.

Buzurgmihri, Zuhrih. Hindisa Dar Mimari (Geometry in Persian Architecture, in Farsi). Tehran: Iranian Cultural Heritage, 1992.

El-Said, Issam and Ayse Parman. 1976. Geometric Concepts in Islamic Art. London: World of Islam Festival Publishing Company.

Emmons, Paul. 2001. The Means and Meanings of Dashed Lines. 89th ACSA Annual Meeting Proceedings, Paradoxes of Progress. Downloadable at: http://apps.acsa-arch.org/resources/ proceedings/indexsearch.aspx?txtKeyword $1=74 \& d d F i e l d 1=4$ (accessed 2 Jan 2016). 
Frascari, Marco. 1991. Monsters of Architecture: Anthropomorphism in Architectural Theory. Savage, Md.: Rowman \& Littlefield.

Ibn Khaldun, Abd Ar Rahman bin Muhammed. 1967. The Muqaddimah: An Introduction to History. 2d ed., 3 vols. Franz Rosenthal, trans. Bollingen Series XLIII. Princeton: Princeton University Press.

Ikhwan al-Safa. 1978. The Epistle on Music of the Ikhwan Al-Safa. Shiloah Amnon, trans. and ed. TelAviv: Tel-Aviv University, Faculty of Fine Arts Council for Culture \& Art, Ministry of Education \& Culture.

Golombek, Lisa, and Donald Newton Wilber. 1988. The Timurid Architecture of Iran and Turan. Princeton Monographs in Art and Archaeology. Princeton: Princeton University Press.

Koliji, Hooman. 2010. Dirineh Khaneh: Sketches from Iranian Architecture. Tehran: Shahid Beheshti University Press (SBU).

Koliji, Hooman. 2015. In-Between: Architectural Drawing and Imaginative Knowledge in Islamic and Western Traditions. Burlington, VT: Ashgate.

Lorzadeh, Hossien. Ihyay-I Hunarhay-I Az Yad Rafih: Mabani Mimari Sunati Dar Iran (Rivival of the Forgotten Arts: Principles of the Traditional Architecture in Iran, in Farsi). edited by Mahnaz Raieszadeh and Hossein Mofid Tehran: Mola Publications, 2010.

Maheronnaqsh, M. 1984. Design and Execution in Persian Ceramics. Tehran: Reza Abbasi Museum Press.

Mayer, Leo Ary. 1956. Islamic Architects and Their Works. Geneva: Albert Kundig.

Necipoğlu, Gülru. 1986. Plans and Models in 15th and 16th Century Ottoman Architectural Practice. Journal of the Society of Architectural Historians 45(3): 224-43.

Necipoğlu, Gülru. 2016. "Ornamental Geometries: An Anonymous Persian Compendium at the Intersection of Visual Arts and Mathematical Sciences." Chapter 1, in: The Arts of Ornamental Geometry: A Persian Compendium on Similar and Complementary Interlocking Figures (Fi Tadākhul al-ashkāl al-mutashābiha aw al-mutawāfiqa, Bibliothèque nationale de France, Ms. Persan 169, fols. 180r-199v), Gülru Necipoğlu. ed. Brill, Supplements to Muqarnas (forthcoming).

Necipoğlu, Gülru and Mohammad Al-Asad. 1995. The Topkapi Scroll : Geometry and Ornament in Islamic Architecture : Topkapi Palace Museum Library Ms H. 1956. Sketchbooks \& Albums. Santa Monica, CA: Getty Center for the History of Art and the Humanities.

Pournader, Hossein. 2000. Sha'rbaf Va Asarash (Sha'rbaf and His Works). Vol. 2, Girih and Karbandi. Tehran: Iranian Cultural Heritage Center, 2000.

Rabbat, Nasser. 1998. Architects and Artists in Mamluk Society: The Perspective of the Sources. Journal of Architectural Education 52(1): 30-37.

Rempel, Lazar I. 1961. Arkhitekturnie ornament Uzbekistana (Architectural Ornament of Uzbekistan). Tashkent: Gos. Izdatel'stov khudozh, lit-ry, UzSSR.

Sarhangi, Reza. 2012. Polyhedral Modularity in a Special Class of Decagram Based Interlocking Star Polygons. Proceedings of Bridges 2012: Mathematics, Music, Art, Architecture, Culture, Reza Sarhangi, ed., 165-174. http://archive.bridgesmathart.org/2012/bridges2012-165.pdf (accessed 2 Jan 2016).

Sha'rbaf, Asghar. 2006. Girih Va Karbandi (Girih and Pattern Making, in Persian). Guzīdah-’i āsāan-i Ustād Aṣghar Shi'rbāf, vol. 1. Tehran: Sazman-i miras farhangi (The Iranian Cultural Heritage Center).

Wilber, Donald. 1956. Book Review of Islamic Architects and Their Works. The Art Bulletin 38(4): 253.

Yousefi, Arash Etemad. 2005. Medieval Islamic and Gothic architectural drawings. Masons, craftsmen and architects. Master's thesis, Massachusetts Institute of Technology.

Hooman Koliji is a designer, author, and an associate professor of architecture at the University of Maryland. He holds a Master of Architecture, a Masters of Landscape Architecture, and a Ph.D. in Architecture and Design Research. Koliji's work examines the realm of "in-between" in the design including intersection of visual representation and spatial experience, and theories of imagination and design. Koliji is the author of books, In-Between: Architectural Drawing and Imaginative Knowledge in Islamic and Western Traditions (Ashgate 2015), and Sketches from Iranian Architecture (Koliji 2010), book chapters, and numerous essays and papers. 